\title{
Pengaruh Likuiditas dan Ukuran Perusahaan terhadap Return Saham pada Perusahaan Manufaktur Sub Sektor Makanan dan Minuman
}

\author{
Hendra Lesmana', Wati Erawati ${ }^{2}$, Husni Mubarok ${ }^{3}$, Ery Suryanti ${ }^{4}$ \\ 1,2,3,4 Universitas Bina Sarana Informatika \\ ${ }^{1}$ hendra.hla@bsi.ac.id , ${ }^{2}$ wati.wti@bsi.ac.id, ${ }^{3}$ husni.hub@bsi.ac.id, ${ }^{4}$ erisuryanti.esi@bsi.ac.id \\ Diterima Direvisi Disetujui \\ 29-09-2020 19-10-2020 18-03-2021
}

\begin{abstract}
This study aims to test whether liquidity and company size have an influence on stock returns in manufacturing companies in the food and beverage sub-sector in 2017-2019. The total population of this study was 26 companies with a total sample of 11 manufacturing companies listed on the Indonesia Stock Exchange with a study period of three years so that the research sample was 33 data. The data used is secondary data from various reliable sources. The sampling technique used was purposive sampling method. The independent variables include liquidity and company size, while the dependent variable is stock returns. Collecting data in this study using secondary data with documentation methods. The method of analysis of this research is using multiple linear regression analysis and t test. Based on the t test shows that liquidity has a significant effect on stock returns company size has an influence on stock returns. The company's ability to pay debts on time will make the stock returns be returned appropriately. Mean while, company size has a positive and insignificant effect on stock returns.
\end{abstract}

Keywords: Liquidity, Company Size, Stock Return,

Abstrak - Penelitian ini bertujuan untuk menguji apakah likuiditas dan ukuran perusahaan memiliki pengaruh terhadap return saham pada perusahaan manufaktur sub sektor makanan dan minuman tahun 2017-2019. Total populasi penelitian ini adalah 26 perusahaan dengan total sampel 11 perusahaan manufaktur yang terdaftar di Bursa Efek Indonesia dengan periode penelitian selama tiga tahun sehingga sampel penelitian 33 data. Data yang digunakan merupakan data sekunder dari berbagai sumber terpercaya. Teknik pengambilan sampel yang digunakan adalah metode purposive sampling. Termasuk variabel independen adalah likuiditas dan ukuran perusahaan sedangkan variabel dependen adalah return saham. Pengumpulan data pada penelitian ini menggunakan data sekunder dengan metode dokumentasi. Metode analisis penelitian ini menggunakan analisis regresi linear berganda dan uji t. Berdasarkan uji t menunjukkan bahwa likuiditas berpengaruh signifikan terhadap return saham, ukuran perusahaan memiliki pengaruh terhadap return saham. Kemampuan perusahaan untuk membayar hutang tepat waktu akan membuat return saham dikembalikan dengan tepat. Sedangkan ukuran perusahaan berpengaruh positif dan tidak signifikan terhadap return saham.

Kata kunci: Likuiditas, Ukuran Perusahaan, Return Saham,

\section{PENDAHULUAN}

Pada tahun 2019 pasar modal di Indonesia mengalami perkembangan. Bursa Efek Indonesia (BEI) kembali berhasil mencatatkan sejumlah pencapaian yang membanggakan. Hal ini berpengaruh pada peningkatan return saham atau tingkat pengembalian berupa keuntungan dan kerugian yang didapatkan oleh para investor yang menanamkan sahamnya pada perusahaan manufaktur terutama perusahan yang bergerak pada sub sektor makanan dan minuman. Menurut Kementerian Industri Republik Indonesia pada tahun 2018 industri makanan dan minuman menjadi andalan dalam memberikan kontribusi pertumbuhan ekonomi di Indonesia. Sepanjang tahun 2018 Industri makanan dan minuman mampu tumbuh sebesar 7,91 persen atau melampaui pertumbuhan ekonomi nasional di angka 5,17 persen. Bahkan, pertumbuhan produksi industri manufaktur besar dan sedang di triwulan IV-2018 naik sebesar 3,90 persen (y-on-y) terhadap triwulan IV-2017, salah satunya disebabkan oleh meningkatnya produksi industri minuman yang mencapai 23,44 persen. Selanjutnya, industri makanan menjadi salah satu sektor yang menopang peningkatkan nilai investasi nasional, yang pada tahun 2018 menyumbang hingga Rp56,60 triliun. Realisasi total nilai investasi di sektor industri manufaktur sepanjang tahun lalu mencapai Rp222,3 triliun. (Kemenparin.go.id, 2018).

Perkembangan perusahaan pada sub sektor makanan dan minuman tersebut membuat investor berlomba-lomba untuk melakukan investasi. Akan 
tetapi sebelum melakukan investasi, investor biasanya terlebih dahulu melakukan evaluasi kinerja perusahaan menggunakan analisis laporan keuangan dengan rasio keuangan yaitu rasio likuiditas (current ratio), likuiditas menurut "(Kariyoto, 2017) merupakan kemampuan suatu perusahaan untuk memenuhi kewajiban keuangan jangka pendek atau kemampuan perusahaan untuk memenuhi kewajiban keuangan pada waktu ditagih, rasio likuiditas sering kali dijadikan tolak ukur bagi para investor dalam menentukan investasi saham". Selain likuiditas ukuran perusahaan juga menjadi pertimbangan investor untuk melakukan investasi saham yang diukur dari jumlah asset diyakini dapat menjadi pertimbangan investor dan manajer dalam penggunaan informasi perusahaan. Ukuran perusahaan menggambarkan besar kecilnya suatu perusahaan yang ditunjukkan oleh total aktiva, jumlah penjualan, rata-rata tingkat penjualan dan rata-rata total aktiva. Perusahaan yang berskala besar akan lebih tinggi harga sahamnya sehingga, hal tersebut tentu mendukung perusahaan untuk mendapatkan return yang lebih besar, dibandingkan dengan perusahaan kecil.

Beberapa studi menemukan bahwa hasil yang ditemukan tidak selalu konsisten antara penelitian yang satu dengan yang lain. Penelitian "(Putra, 2019) mengatakan bahwa likuiditas berpengaruh positif dan tidak signifikan terhadap return saham". Hasil pengujian hipotesis menunjukkan bahwa nilai koefisien 0,000 maka Ho ditolak dan H1 diterima dengan signifikansi 0,226 yang lebih besar dari taraf signifikansi yang ditentukan sebesar 0,05. Dengan demikian likuiditas berpengaruh positif dan tidak signifikan, sedangkan menurut "(Susanti, 2017) menyatakan bahwa Current Ratio (CR) berpengaruh negatif tidak signifikan terhadap terhadap return saham pada perusahaan yang terdaftar di Bursa Efek Indonesia periode tahun 2010-2016".

Untuk ukuran perusahaan "(Susanti, 2017) menyatakan bahwa Ukuran Perusahaan (Firm Size) berpengaruh positif signifikan terhadap return saham", sedangkan menurut (Dewi, 2019) "ukuran perusahaan berpengaruh terhadap return saham pada perusahaan yang terdaftar di Bursa Efek Indonesia periode tahun 2010-2016".

Dari latar belakang dan fenomena yang terjadi maka dapat disimpulkan bahwa rasio likuiditas dan ukuran perusahaan mempengaruhi return saham di karenakan rasio likuiditas mampu memprediksi return saham melalui laporan keuangan sedangkan ukuran perusahaan dapat mempengaruhi return melalui semakin besar ukuran perusahaan maka semakin besar harga saham yang akan meningkatkan nilai return saham.

Berdasarkan

fenomena dan ketidakkonsistenan hasil penelitian penulis melakukan penelitian mengenai Pengaruh Likuiditas dan Ukuran Perusahaan Terhadap Return Saham pada
Perusahaan Manufaktur Sub Sektor Makanan dan Minuman di Bursa Efek Indonesia Periode Tahun 2017-2019.

\section{METODE PENELITIAN}

Jenis penelitian yang digunakan pada penelitian ini adalah dengan pendekatan kuantitatif asosiatif. Dengan jenis data menggunakan data sekunder yang berasal dari publikasi laporan keuangan perusahaan manufaktur yang terdaftar di Bursa Efek Indonesia pada sub sektor makanan dan minuman dan telah melakukan listing atau publikasi.

Berdasarkan data yang didapatkan dari laporan keuangan perusahaan manufaktur terdapat 26 perusahaan manufaktur yang masuk dalam populasi penelitian.

Teknik pengambilan sampel yang digunakan pada penelitian ini yaitu metode non random dengan purposive samping dengan kriteria pengambilan sampel sebagai berikut:

a. Perusahaan selama periode tiga tahun (20172019) telah melakukan publikasi laporan keuangan dengan menggunakan mata uang Rupiah (IDR).

b. Objek penelitian adalah perusahaan manufaktur pada sub sektor makanan dan minuman yang terdaftar di Bursa Efek Indonesia.

c. Perusahaan bersangkutan secara konsisten terdaftar pada tahun 2017-2019 dengan pembukuan laporan keuangan yang dipublikasi berakhir pada periode 31 Desember.

Berdasarkan kriteria di atas maka terdapat 11 perusahan yang dapat menjadi sampel. Periode data yang digunakan dalam penelitian ini selama 3 tahun sehingga dapat diketahui jumlah data penelitian adalah 33 data (11 x 3 tahun).

Metode analisis data yang digunakan adalah uji statistik deskriptif, uji asumsi klasik yang terdiri dari uji normalitas, heterokedastisitas, autokorelasi dan multikolenieritas. Pengolahan data pada penelitian ini meggunakan aplikasi SPPS (Statictical Program of Social Science) Versi 24.

Analisis data yang digunakan adalah uji analisis regresi linier berganda, uji parsial, uji simultan dan uji koefisien determinasi. Variabel yang digunakan dalam penelitian ini terdiri dari variabel independen yaitu likuiditas (CR) dan ukuran perusahaan. Variabel dependen dalam penelitian ini adalah return saham.

\section{HASIL DAN PEMBAHASAN}

Hasil penelitian ini adalah untuk mengetahui pengaruh likuiditas dan ukuran

perusahan terhadap return saham. Hasil penelitian terdiri dari analisis statistik, uji asumsi klasik dan uji hipotesis. 


\section{Deskriptif Penelitian}

Analisis deskriptif menggambarkan data atas variabel penelitian. Analisis deskriptif menggambarkan jumlah data $(\mathrm{N})$, nilai rata-rata (mean), nilai maksimum, nilai minimum, dan Standar penyimpangan data (standar deviasi).

Tabel 1 Descriptive Statistics

\begin{tabular}{|l|r|r|r|r|r|}
\hline & N & Minimum & Maximum & Mean & \multicolumn{1}{|c|}{ Std. Deviation } \\
\hline Likuiditas & 33 &, 78 & 8,64 & 2,8133 & 1,94609 \\
\hline $\begin{array}{l}\text { Ukuran } \\
\text { Perusahaan }\end{array}$ & 33 & 14,74 & 30,54 & 23,5224 & 5,90173 \\
\hline Return Saham & 33 &, 43 & 5,47 & 1,9058 & 1,14374 \\
\hline $\begin{array}{l}\text { Valid N } \\
\text { (listwise) }\end{array}$ & 33 & & & & \\
\hline
\end{tabular}

Sumber : Lampiran SPSS (data diolah 2020)

\section{Uji Asumsi Klasik}

\section{Uji Normalitas}

Uji normalitas digunakan dalam model regresi variabel terikat dan variabel bebas untuk melihat keduanya mempunyai distribusi normal ataukah tidak. Model regresi yang berdistribusi normal atau mendekati normal adalah model regresi yang baik. "(Johar, 2017) mengatakan bahwa uji normalitas dapat menggunakan test KlomogorovSmirnov, data dapat dikatakan memiliki distribusi normal jika nilai Asymp. Sig. > 0,05”.

Tabel 2 Uji Normalitas

\begin{tabular}{|c|c|c|}
\hline \multicolumn{3}{|c|}{ One-Sample Kolmogorov-Smirnov Test } \\
\hline & & Unstandardized Residual \\
\hline \multicolumn{2}{|l|}{$\mathrm{N}$} & 33 \\
\hline \multirow[t]{2}{*}{ Normal Parameters ${ }^{\mathrm{a}, \mathrm{b}}$} & Mean & ,0000000 \\
\hline & Std. Deviation & ,34271772 \\
\hline \multirow[t]{3}{*}{ Most Extreme Differences } & Absolute &, 150 \\
\hline & Positive & 150 \\
\hline & Negative &,- 182 \\
\hline \multicolumn{2}{|l|}{ Test Statistic } & 228 \\
\hline \multicolumn{2}{|l|}{ Asymp. Sig. (2-tailed) } & 149 \\
\hline
\end{tabular}

Berdasarkan tabel uji normalitas di atas menunjukkan nilai Kolmogorov-Smirnov sebesar 0,228 dan nilai Asymp. Sig. sebesar 0,149 yang artinya lebih besar dari 0,05 . Dengan demikian dapat disimpulkan bahwa data tersebut berdistribusi normal dan dapat dilanjutkan untuk dilakukan penelitian
Multikolinieritas menunjukan hubungan yang antara variabel bebas mendekati sempurna. "(Johar, 2017:179) mengatakan bahwa data tidak terjadi multikolinearitas jika nilai Tolerance $>0,1$ dan nilai VIF < 10. Berikut ini hasil pengujian tersebut".

\section{Uji Multikolinieritas}

Tabel 3 Uji Multikolinearitas

\begin{tabular}{|l|l|r|r|}
\hline \multirow{2}{*}{ Model } & \multicolumn{2}{|c|}{ Collinearity Statistics } \\
\cline { 2 - 4 } & Tolerance & \multicolumn{1}{c|}{ VIF } \\
\hline \multirow{3}{*}{1} & (Constant) & & \\
\cline { 2 - 4 } & Likuiditas &, 806 & 1,105 \\
\cline { 2 - 4 } & Ukuran Perusahaan &, 804 & 1,108 \\
\hline
\end{tabular}

Sumber : Data Sekunder diolah SPSS

Tabel diatas, menunjukkan bahwa data pada variabel bebas tidak mengandung adanya gejala korelasi yang kuat antara sesama variabel bebas yang telah diperoleh dalam karena semua nilai VIF yang dihitung lebih kecil dari 10 dan nilai tolerance diatas 
0,1 maka dapat disimpulkan tidak terdapat multikolinieritas diantara variabel bebas.

\section{Uji Autokorelasi (Durbin Watson)}

Uji autokorelasi dilakukan untuk megetahui apakah ada korelasi antara kesalahan pengganggu pada periode $\mathrm{t}$ dengan kesalahan pada periode sebelumnya pada model regresi yang digunakan.

Dalam model regresi yang baik adalah tidak terjadi autokorelasi. "(Nisfianoor, 2013:111) melihat tabel Durbin Watson dengan kriteria pengujian autokorelasi jika dU< DW < 4-dU maka tidak terjadi autokorelasi". Total jumlah sampel dalam penelitian ini adalah 33 data.

\section{Tabel 4 Uji Autokorelasi}

\begin{tabular}{|l|r|r|r|r|rr|}
\hline Model & R & R Square & $\begin{array}{c}\text { Adjusted R } \\
\text { Square }\end{array}$ & $\begin{array}{c}\text { Std. Error of the } \\
\text { Estimate }\end{array}$ & Durbin-Watson \\
\hline 1 &, $928^{\mathrm{a}}$ &, 809 &, 728 & 2,54020940 & & 1,920 \\
\hline
\end{tabular}

a. Predictors: (Constant), Ukuran Perusahaan,Likuiditas

b. Dependent Variable: Return Saham

Sumber : Data Sekunder diolah SPSS

Dari hasil SPSS di atas dapat dilihat bahwa Nilai Durbin Watson pada signifikansi 5\% yaitu sebesar 1,92. Oleh karena nilai Durbin Watson 1,920 lebih besar dari nilai tabel atau batas atas (du) yaitu 1,887. Maka dapat disimpulkan bahwa model regresi ini menunjukkan tidak terdapat autokorelasi.

\section{Uji Heterokesdastisitas}

Uji heterokesdastisitas adalah untuk mengetahui apakah variabel residual absolute sama atau tidak untuk semua pengamatan. Model regresi yang baik adalah jika tidak terjadi heterokesdastisitas. Menurut "(Nisfianoor, 2013:181) melihat hasil heterokesdastisitas dapat melalui scaterplot dengan titik-titik yang menyebar secara acak tanpa pola tertentu"

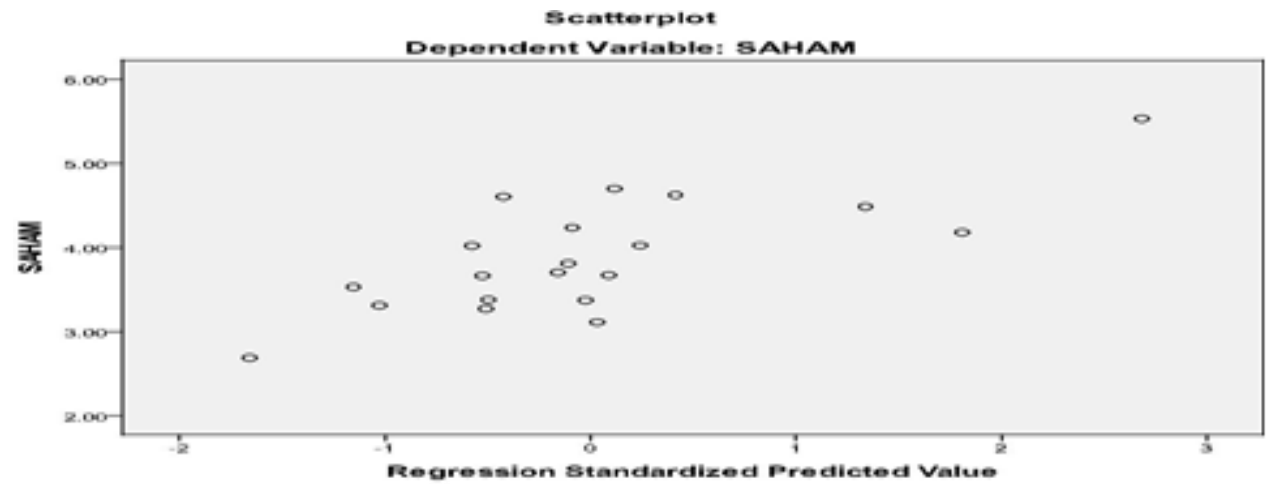

Berdasarkan diagram pancar maka dapat dilihat bahwa penyebaran residual tidak homogen. Hal tersebut dapat dilihat dari plot yang menyebar dan tidak membentuk suatu pola tertentu. Dengan hasil demikian terbukti bahwa tidak terjadi gejala homokesdastisitas atau persamaan regresi memenuhi asumsi non heterokesdastisitas.

\section{Koefisien Determinasi}

Untuk mengetahui seberapa erat hubungan antara variabel bebas dengan variabel tidak bebas kitadapat menggunakan analisis koefisien determinasi Adapun hasil analisis koefisien determinasi tersebut dapat dilihat pada tabel berikut: 
Tabel 5 Koefisien Determinasi

\begin{tabular}{|l|r|r|r|r|rr|}
\hline Model Summary \\
\hline Model & \multicolumn{1}{c|}{ R } & R Square & $\begin{array}{c}\text { Adjusted R } \\
\text { Square }\end{array}$ & $\begin{array}{c}\text { Std. Error of the } \\
\text { Estimate }\end{array}$ & Durbin-Watson \\
\hline 1 &, $928^{\mathrm{a}}$ &, 809 &, 728 & 2,54020940 & 1,920 \\
\hline
\end{tabular}

a. Predictors: (Constant), UP, CR

b. Dependent Variable: RETURN SAHAM

Sumber : Data Sekunder diolah SPSS

Tabel 4.5 menunjukan nilai dari Adjusted $\mathrm{R}$ Square sebesar 0,728 yang berarti bahwa sebesar $72,8 \%$ variasi variabel terikat dapat dijelaskan oleh variasi dari variabel bebas. Oleh karena itu, dapat disimpulkan bahwa sebesar $72,8 \%$ variabel return saham dipengaruhi oleh likuiditas dan ukuran perusahaan. Sedangkan sisanya sebesar 27,2\%. dipengaruhi oleh variabel lain selain variabel yang digunakan dalam model penelitian ini.

\section{Uji F}

Uji $F$ digunakan untuk mengetahui nilai yang memberikan kuatnya pengaruh atau hubungan dua variabel atau lebih secara bersama-sama. Melalui uji $\mathrm{F}$ dapat diketahui apakah regresi berganda yang telah didapatkan secara bersama-sama berpengaruh terhadap return saham atau tidak ada pengaruh. Adapun hasil uji F statistik dapat dilihat pada tabel berikut

Tabel 6 Uji F

ANOVA $^{\mathrm{a}}$

\begin{tabular}{|l|l|c|c|c|c|c|}
\hline \multicolumn{2}{|l|}{ Model } & Sum of Squares & Df & Mean Square & F & Sig. \\
\hline \multirow{4}{*}{1} & Regression & 4,697 & 3 & 1,566 & 6,484 &, $003^{\mathrm{a}}$ \\
\cline { 2 - 7 } & Residual & 3,857 & 16 &, 241 & & \\
\cline { 2 - 7 } & Total & 8,554 & 19 & & & \\
\hline
\end{tabular}

a. Dependent Variable: RETURN SAHAM

b. Predictors: (Constant), UP, CR

Sumber : Data Sekunder diolah SPSS

Berdasarkan Tabel 4.6 dapat diketahui bahwa $\mathrm{F}$ hitung $=6,484$ dengan tingkat signifikan sebesar $0,003<0,05$ sehingga dapat disimpulkan bahwa variabel likuiditas, dan ukuran perusahaan berpengaruh terhadap return saham.

\section{Hasil Pengujian Hipotesis}

Dalam menguji hipotesis peneliti menggunakan uji regresi linear berganda. Uji hipotesis digunakan untuk mengetahui pengaruh likuiditas dan ukuran perusahaan terhadap return saham pada perusahaan manufaktur sub sektor makanan dan minuman tahun 2017-2019 dengan mengguakan software SPSS.

Tabel 7 Analisis Regresi Berganda

\begin{tabular}{|c|c|c|c|c|c|c|}
\hline \multicolumn{7}{|c|}{ Coefficients $^{\mathrm{a}}$} \\
\hline & & \multicolumn{2}{|c|}{$\begin{array}{l}\text { Unstandardized } \\
\text { Coefficients }\end{array}$} & \multirow{2}{*}{$\begin{array}{c}\begin{array}{c}\text { Standardized } \\
\text { Coefficients }\end{array} \\
\text { Beta } \\
\end{array}$} & \multirow[b]{2}{*}{$\mathrm{t}$} & \multirow[b]{2}{*}{ Sig. } \\
\hline \multicolumn{2}{|c|}{ Model } & $\mathrm{B}$ & Std. Error & & & \\
\hline \multirow[t]{3}{*}{1} & (Constant) & 1,664 & ,910 & & 1,829 &, 027 \\
\hline & Likuiditas & ,792 &, 106 &, 135 & 2,912 &, 042 \\
\hline & Ukuran Perusahaan & ,230 & 035 & , 102 & 2,477 &, 025 \\
\hline
\end{tabular}

Dalam penelitian ini, penulis melakukan analisis regresi linier berganda untuk mengetahui pengaruh likuiditas dan ukuran perusahaan terhadap return saham. Berdasarkan tabel 4.7 di atas dapat diketahui persamaan regresinya:

$\mathrm{Y}=\alpha+(\mathrm{LK}) \mathrm{X} 1+(\mathrm{UP}) \mathrm{x} 2+\mathrm{e}$

$\mathrm{Y}=1.664+0,792 \mathrm{X} 1+0,230 \mathrm{X} 2$
$\mathrm{Y} \quad=$ Return Saham

$\alpha=$ Konstanta

LK = Likuiditas

UP = Ukuran Perusahaan

Persamaan regresi linear dapat dijelaskan berikut:

a. Konstanta 1,664 artinya jika semua variabel = 0 maka nilai return saham sebesar 1,664. 
b. Koefisien regresi variabel likuiditas sebesar 0,792 , artinya jika nilai likuiditas naik $1 \%$ berarti nilai return saham naik $0,792 \%$.

c. Koefisien regresi variabel ukuran perusahaan sebesar 0,230, artinya jika ukuran perusahaan semakin $1 \%$ berarti return saham akan naik $0,230 \%$.

\section{Uji T (Parsial)}

Uji statistik t digunakan untuk mengetahui pengaruh variabel bebas (independen) terhadap variabel terikat (dependen) dengan menggunakan perbandingan antara t hitung dengan $t$ tabel. Hasil uji$\mathrm{t}$ pengaruh variabel independen terhadap variabel dependen adalah sebagai berikut:

a. Pengaruh Likuiditas terhadap Return Saham

Berdasarkan tabel 7 dapat dilihat nilai $\mathrm{T}$ hitung dibandingkan dengan $\mathrm{T}$ tabel yaitu (2,912> 2,042), dapat disimpulkan bahwa Ho ditolak dan Ha diterima maka Likuiditas berpengaruh positif terhadap return saham

b. Pengaruh Ukuran Perusahaan terhadap Return Saham

Berdasarkan tabel 7 dapat dilihat nilai $\mathrm{T}$ hitung dibandingkan dengan $\mathrm{T}$ tabel yaitu $(2,477>$ 2,042), dapat disimpulkan Ho ditolak dan Ha diterima maka Ukuran Perusahaan berpengaruh positif terhadap return saham

Sedangkan berdasarkan nilai signifikansi hasil pengujian membuktikan bahwa variabel likuiditas memiliki nilai signifikan $0,042<0,05$. Hal ini membuktikan bahwa likuiditas berpengaruh terhadap return saham. Kemampuan perusahaan untuk membayar hutang tepat waktu akan membuat return saham dikembalikan dengan tepat. Hal tersebut juga dijelaskan dengan teori sinyal, teori sinyal, menurut "(Hartono, 2013) informasi dalam perusahaan berupa kemampuan perusahaan dalam memenuhi kewajiban jangka pendeknya misalnya pembayaran hutang dalam teori sinyal informasi yangdiberikan oleh kepada pihak eksternal merupakan sinyal positif yang berpengaruh pada opini investor dan kreditor atau pihak lain yang berkepentingan". Teori sinyal menyatakan bahwa perusahaan yang berkualitas baik dengan sengaja akan memberikan sinyal pada pasar, dengan demikian pasar diharapkan dapat membedakan perusahaan yang berkualitas baik dan buruk. Sinyal yang baik harus dapat ditangkap pasar dan di persepsikan baik agar tidak mudah ditiru oleh perusahaan yang memiliki kualitas yang buruk (Hartono, 2013). Teori sinyal berisi informasi tentang perusahaan yang dapat mempengaruhi keputusan investasi pihak di luar perusahaan. Bagi investor dan pelaku bisnis informasi merupakan unsur penting, dan pada hakekatnya menyajikan keterangan, catatan atau gambaran baik untuk keadaan masa lalu, saat ini maupun keadaan masa yang akan datang bagi kelangsungan hidup suatu perusahaan dan bagaimana pasaran efeknya. Dipasar modal Informasi sangat diperlukan oleh investor sebagi alat analisis untuk mengambil keputusan investasi, dengan catatan informasi harus lengkap, relevan, akurat dan tepat waktu. Menurut "(Jogiyanto, 2015) informasi merupakan pengumuman yang disebarkan berupa sinyal pada investor yang dapat dijadikan pertimbangan dalam mengambil keputusan investasi”. Jika pengumuman di nilai berdampak positif, diharapkan pengumuman tersebut diterima oleh pasar. Secara logika jika perusahaan mampu memenuhi kewajibannya, maka perusahaan dinilai sebagai perusahaan yang baik semakin meningkat nilai likuiditas maka nilai return saham ikut meningkat .

Hasil penelitian ini didukung Penelitian "(Putra, 2019) mengatakan bahwa likuiditas berpengaruh positif dan tidak signifikan terhadap return saham". Hasil pengujian hipotesis menunjukkan bahwa nilai koefisien 0,000 artinya $\mathrm{H} 1$ diterima dan $\mathrm{H} 0$ ditolak dengan signifikansi 0,226 lebih besar dari 0,05 (taraf signifikansi). Dengan demikian likuiditas berpengaruh positif dan tidak signifikan, sedangkan menurut "(Susanti, 2017) menyatakan bahwa Current Ratio (CR) berpengaruh negatif tidak signifikan terhadap terhadap return saham pada perusahaan yang terdaftar di Bursa Efek Indonesia periode tahun 2010-2016".

\section{Pengaruh Ukuran Perusahaan terhadap Return} Saham

Berdasarkan hipotesis kedua menunjukkan bahwa ukuran perusahaan berpengaruh positif dan signifikan terhadap return saham. Hasil pengujian hipotesis menunjukkan nilai signifikansi 0,025 <0,05 dengan demikian ukuran perusahaan berpengaruh positif dan signifikan terhadap return saham. Ukuran perusahaan yang semakin besar dapat mempengaruhi dana yang akan dikeluarkan. Ukuran perusahaan yang besar dijadikan indikator dalam menggambarkan tingkat risiko bagi investor untuk melakuakn investasi pada perusahaan tersebut. Hasil penelitian ini sejalan dengan penelitian "(Susanti, 2017) menyatakan bahwa Ukuran Perusahaan (Firm Size) berpengaruh positif signifikan terhadap return saham dengan nilai signifikan $0,02<0,05$, sedangkan menurut "(Dewi, 2019) ukuran perusahaan berpengaruh terhadap return saham pada perusahaan yang terdaftar di Bursa Efek Indonesia periode tahun 2010-2016".

\section{KESIMPULAN}

Kesimpulan dari penelitian ini adalah, likuiditas berpengaruh terhadap return saham. Kemampuan perusahaan untuk membayar hutang tepat waktu akan membuat return saham dikembalikan dengan tepat. Sedangkan ukuran perusahaan berpengaruh positif dan tidak signifikan terhadap return saham. Semakin besar ukuran perusahaan, maka semakin besar dana yang akan dikeluarkan. Saat melakukan investasi pada suatu perusahaan investor mekihat ukuran perusahaan sebagai suatu indikator yang menggambarkan tingkat resiko. Untuk itu bagi 
masyarakat atau investor yang ingin berinvestasi saham pada perusahaan-perusahaan go public hendaknya untuk memperhatikan kinerja keuangan perusahaan dan pengaruhnya terhadaap return saham sebagai bahan pengambilan keputusan.

\section{REFERENSI}

Susanti. (2017). Pengaruh penggunaan Aset, Likuiditas, Ukuran Perusahaan, Dan Kualitas Audit Terhadap Kualitas Informasi Laporan Keuangan. Jurnal Akuntansi Dewantara.

Kariyoto, K. (2017).Preparation of Standard Unit Price of Goods and Services (SHBJ) in East Java Provincial Government. International Journal of Social and Local Economic Governance. https://doi.org/10.21776/ub.ijleg.2017.003.01. $\underline{4}$

Putra, M. (2019). Pengaruh Profitabilitas, Leverage, Likuiditas dan Ukuran perusahaan terhadap Return Saham pada Perusahaan yang teraftar di BEI. E-Jurnal Manajemen UNUD.

Martiani, N. L. D. (2019). PENGARUH RASIO KEUANGAN TERHADAP HARGA SAHAM PADA PERUSAHAAN MANUFAKTUR SEKTOR INDUSTRI BARANG KONSUMSI YANG TERDAFTAR DI BURSA EFEK INDONESIA PERIODE TAHUN 2013-2016. Jurnal Pendidikan Ekonomi Undiksha. https://doi.org/10.23887/jjpe.v10i2.20160.

Dewi, (2017). Pengaruh Inflasi, Prifitabilitas dan Ukuran Perusahaan terhadap Return Saham. E-Jurnal Akuntansi.
Johar. (2017). SPSS 24 Untuk Penelitian dan Skripsi. In PT Gramedia.

Nisfiannoor, Muhammad. (2013).Pendekatan Statistika Modern Untuk Ilmu Sosial. Jakarta : Salemba Humanika.

Hartono, J. (2013). Teori Fortofolio dan Analisis Investasi. Edisi Kedelapan. Metodologi Penelitian Bisnis.

Jogiyanto. (2015). Teori portofolio dan analisis investasi (edisi Kesepuluh). In Yogyakarta: $B P F E$.

Kementrian Perindustrian (2019). Perkembangan Perusahaan Manufaktur Sektor Makanan dan Minuman semakin bersaing. www.kemenparin.go.id

Republik Indonesia. (1995a). Undang-Undang No. 8 Tahun 1995 tentang Pasar Modal. Lembaran Negara Republik Indonesia Tahun 1995. No 3608. Jakarta.

Republik Indonesia (2018). Peraturan Otoritas Jasa Keuangan Republik Indonesia No IX.A.I tentang ketentuan umum pengajuan, pernyataan dan pendaftaran perusahaan go public. Lembaran Negara Republik Indonesia Tahun 2018.

Republik Indonesia (2008b). Undang-Undang No.20 Tahun 2008 tantang Usaha Kecil, Menengah. Tambahan Lembaran Republik Indonesia Tahu 2008. No 4866. Jakarta. 